\title{
CASH POOLING AS A TOOL FOR OPTIMIZATION OF ENTERPRISE COMPANY FINANCIAL ACTIVITY
}

\author{
Haytham Shakarna \\ Peoples' friendship University of Russia (RUDN University) \\ $\mathrm{Ph}$ student of the Department of civil law and procedure \\ and international private law
}

\begin{abstract}
The financial sphere in business plays a particularly important role. Competent placement of funds is directly related to the efficiency of the company. In this regard, such a financial instrument as cash pooling is of great importance in modern economic conditions. The relevance of this research appears in the active use of cash pooling in the business world, due to its positive impact on the development of the company and on its economic growth and increased profitability and competitiveness in the market.

The purpose of the work is to reveal the essence of such a phenomenon as cash pooling.

The objectives of the study are to identify the mechanisms and features of the use of this tool for managing the financial activities of a company, to identify the role of cash pooling in modern conditions of business development.

Research methodology includes search for data sources, methods of data analysis reliability of data, reliability analysis, validity, data quality management, inclusion criteria, ethical consideration and dissemination of result and its utilization approaches.

It is important for each company to optimize processes of financial development. Cash pulling is an effective instrument in the modern business world. Liquidity bundling offers obvious business advantages. All liquid capital is collected in one place, is centrally managed, and can be optimally distributed throughout the group.
\end{abstract}

Key words: cash pooling, cash management, liquidity bundling, financial tool, financial flows, banking product, economic advantages, economic risks.

\section{Methodology}

The scientific development of the content of this article is carried out based on the general scientific method of historical materialism. General scientific methods of cognition are used: dialectical, hypothetical-deductive method, generalization, 


\section{МЕЖДУНАРОДНЫЕ НАУЧНЫЕ ЧТЕНИЯ ИМЕНИ ЛАУРЕАТА НОБЕЛЕВСКОЙ ПРЕМИИ П.Л. КАПИЦЫ}

induction and deduction, analysis and synthesis, empirical description. The study also used private science methods: juridical-dogmatic, statistical method, method of comparative legal analysis, other.

\section{Introduction}

Everything in one place - this is one way of describing cash pooling. Cash pooling - liquidity bundling within a company is a special form of group financial management, when one group company's credit balance is used to offset the negative balance of another. This offers a number of economic advantages, but it is also associated with potential taxes and company law risks. It is an effective mechanism to set up and operate a cash pooling system [1].

The relevance of this research appears in the active use of cash pooling for welfare of the company and on its economic growth and increased profitability and competitiveness in the market.

The purpose of the work is to reveal the essence of such a phenomenon as cash pooling, to identify the mechanisms and features of the application of this tool for managing the financial activities of a company.

Research methodology includes search for data sources, methods of data analysis reliability of data, reliability analysis, validity, data quality management, inclusion criteria, ethical consideration and dissemination of result and its utilization approaches.

Cash pooling, also known as liquidity bundling, is a special form of liquidity management. It is mainly used in groups in which several companies are organized under the management of a controlling company. Although the individual companies are legally independent, since the group as a whole acts as a strategic unit, mutual financial support and distribution of liquidity among the individual companies is in the interests of all parties involved [11].

As the companies in a group are organized independently of each other, their financial situation may well differ. This also has an impact on their liquidity or liquidity requirements (i.e. cash and cash equivalents). While one company finances itself with loans at market interest rates, another may have financial investments that are less profitable. To remedy this imbalance, a cash pooling system can be set up. This is usually run by a central financial management team organized by the parent company [1].

Definition: Cash pooling is a technique used to balance funds within a group of companies. The term consists of the words "cash" for money and "pooling" for merger. 


\section{МЕЖДУНАРОДНЫЕ НАУЧНЫЕ ЧТЕНИЯ ИМЕНИ ЛАУРЕАТА НОБЕЛЕВСКОЙ ПРЕМИИ П.Л. КАПИЦЫ}

The parent company acts as a "cash pool leader" - or it assigns this task to one of its group companies. This cash pool leader then withdraws excess liquidity from the participating companies and collects it (for example, for investments) on a "master account." The money is then used to cover the financial requirements of group companies with low-interest loans in order to prevent higher borrowing rates, or, in extreme cases, insolvencies. Receivables and payables are exclusively settled internally: The companies paying in the money have a repayment claim (without notice in an emergency) against the master account, while the borrower has a repayment obligation [10].

\section{Cash pooling: essence and functions}

Cash pooling is a kind of financial regulation, a special mechanism for operating cash flows associated with the multinational banking system. Interstate corporations place their finances in numerous accounts in different banking and credit organizations in different countries. This method of placing funds and carrying out transactions with different bank accounts, hides the total income of the corporation and keeps the financial situation of the interstate corporation as a whole a secret [2].

\section{Advantages and disadvantages of cash pooling}

SWOT analysis will help determine the advantages and disadvantages of this product in its relationship with banks and businesses. A SWOT analysis makes it possible to describe the strengths and weaknesses of the transaction for pooling the company's cash, as well as identify individual advantages for banks, prospects for the enterprise, or perceived risks that may arise in the process of applying the pooling of funds [7].

SWOT analysis of cash pooling allows us to find out that it is problematic for banking organizations to carry out transactions with this product. In this regard, it is necessary to optimize the communication mechanisms, as well as the cost reduction system. However, working with this product is a great advantage for a banking organization, as a result of which the number of clients increases, and, consequently, incomes. As a result of the fact that banks always aim to gain income and take a firm place in market conditions, the bank needs to work with products that are popular with consumers and monitor economic indicators. As a result, banking organizations need regular development and implementation of new modern effective products to strengthen their positions in the market [2].

The main advantage of cash pooling is that the capital available throughout the group is better used and the need for borrowed capital is reduced. External funds are only used if the group's internal liquidity balance is insufficient to cover capital 


\section{МЕЖДУНАРОДНЫЕ НАУЧНЫЕ ЧТЕНИЯ ИМЕНИ ЛАУРЕАТА НОБЕЛЕВСКОЙ ПРЕМИИ П.Л. КАПИЦЫ}

requirements. In addition, costs can also be saved in the procurement of capital (loans, bonds, etc.). As a rule, a top management group can negotiate better conditions than an individual group company. In addition, procurement costs are reduced if just one unit has to deal with them. Central cash management also has the advantage for group management that it provides a direct insight into the liquidity of the individual group companies. This makes it easier to predict financial crises and plan appropriate counter measures [7].

However, this is also the biggest disadvantage of cash pooling: Since the cash pool leader handles liquidity management centrally, the group companies lose economic independence. This is particularly detrimental to the more solvent pool participants. On the other hand, financially weak companies may rely too much on the cash pooling system and neglect their own liquidity planning [8].

Liability risk is another disadvantage of cash pooling: If a group company encounters problems and runs into financial difficulties, this has a direct impact on the group as a whole via the cash pool. It is therefore very important to maintain an effective management and early warning system linked to the cash pooling system.

Table 1

\section{Pros and cons of cash pooling}

\begin{tabular}{|l|l|}
\hline \multicolumn{2}{|c|}{ Pros and cons of cash pooling } \\
\hline \multicolumn{1}{|c|}{ Advantages and chances } & \multicolumn{1}{c|}{ Disadvantages and risks } \\
\hline - Interest rate optimization for intra- & - Loss of economic group companies' \\
group investments or loans & economic independence \\
- Optimal use of internal resources & - Liability risk at group level \\
- Reduction of the need for borrowed & - Increased (abstract) insolvency risks \\
capital & - Implementation and administrative \\
- Generally better financial & costs \\
performance of the group & - Legal and tax pitfalls \\
- Overview of the liquidity of group & \\
companies and corresponding controls & \\
\hline
\end{tabular}

\section{Genuine and fake cash pools}

In practice, cash pools can actually ("physically") or only virtually be set up and operated. In the first case, the cash pool leader really has a master account to which one group company pays in excess funds and from which the other draws 


\section{МЕЖДУНАРОДНЫЕ НАУЧНЫЕ ЧТЕНИЯ ИМЕНИ ЛАУРЕАТА НОБЕЛЕВСКОЙ ПРЕМИИ П.Л. КАПИЦЫ}

liquidity. They can leave the funds where they are and only allow them to flow virtually between the companies and the master account (known as notional pooling). In this case, the debit and credit interest of the individual companies is still calculated on the master account. This works because the banks are prepared, after consultation, to grant their loans to the individual companies at conditions that they would grant to the central cash pool leader [1].

However, this model is more complicated from a billing point of view than real cash pooling. The fake variant offers a particular advantage in this respect: Since there is no real cash flow, there are no real receivables or liabilities that could be legally questionable under certain circumstances (see below). Internationally active companies in the eurozone sometimes also use hybrid cash pooling. With a mixture of the two models, the real variant is used within the eurozone and the fake cash pooling is used in exchanges with companies in other currency areas. On the one hand, this avoids the expense of the otherwise necessary currency conversions, like hedging transactions. On the other hand, there are sometimes considerable legal hurdles to overcome for genuine cash pooling across national borders [9].

\section{Legal aspects of cash pooling. Cash pooling and its pitfalls}

For a long time, central liquidity management in corporations did not have a good reputation when it came to the law - especially for reasons concerning capital maintenance in corporations. Under certain circumstances, even corporation shareholders could be held liable in an emergency. Another problem can arise if companies in a group borrow money. It is a hidden distribution of profits under excessively favorable conditions, with corresponding tax consequences. These favorable conditions could be an unusually low interest rate or a credit security waiver [1].

More problems could arise with regards to company law: Under certain circumstances, a capital contribution by the cash pool leader as shareholder of a group company can be interpreted as a hidden contribution in kind. This applies if a company loan is repaid to the cash pool. This means that if this group company were to go bankrupt, the cash pool leader as a shareholder would have to pay the contribution again [6].

If, on the other hand, the group company's balance on the master account is balanced or positive, this can be a so-called back and forth payment, if a contribution paid in by the cash pool leader as shareholder of a group company subsequently lands on the master account as liquidity contribution. Even then, the contribution is deemed 


\section{МЕЖДУНАРОДНЫЕ НАУЧНЫЕ ЧТЕНИЯ

not to have been made because the group company does not have the money itself, but only a claim against the cash pool.

The situation can be aggravated by these problems if a company doesn't document its cash pooling activities sufficiently or not at all. The competent authorities or courts may conclude from this that tax and/or company law rules were deliberately circumvented [4].

\section{Cross-border cash pooling}

The legal situation when it comes to cross-border cash pooling (also known as multi-currency pooling) is even more complex, i.e. when companies domiciled abroad participate with their respective national currencies. As there are no worldwide legal compliance standards, the cash-pooling laws of individual states involved must be taken into account when setting up a system like this. Cash pooling is also prohibited in many countries with restrictive financial systems, such as India. So, funds from a local company cannot simply flow into a master account (this is referred to as "trapped cash") [5].

To be on the safe side when it comes to tax documentation, you should consult an expert tax advisor, a cash pooling bank or a specialist service provider.

\section{How cash pooling works in practice}

Setting up a cash pooling system may require some effort, depending on how many companies are involved and whether foreign companies are included. A thorough preparation phase is recommended, the first step of which is an analysis of the group: What are its structures, which companies are suitable as participants, and what are their legal framework conditions (especially for foreign companies)? Prior to implementation, the group units can be informed in workshops about the structure and functioning of the planned cash pooling system. Of particular interest are the leading and trailing edges for those involved as well as liability issues. Security is provided by a written contract, which should cover the following contents, among others:

- Conditions and credit limits

- Mutual loan granting

- Rights and obligations of use

- Arrangements for loan repayment

- Information rights

- Notice

- Admission of new participants 


\section{МЕЖДУНАРОДНЫЕ НАУЧНЫЕ ЧТЕНИЯ

- Special rights of the cash pool leader

A characteristic feature of a balanced contract negotiation is that no party is overburdened, as otherwise the liability limitation is threatened [3].

\section{Important: the cost structures}

You should then gain an overview of the subsidiaries account structures. A bank that offers cash pooling is responsible for the actual processing of payments. The costs incurred play a central role in this, as the solution should be cheaper than the conventional banking transactions of the individual companies. Technical questions concern the file format for transactions (e.g. XML) and the times when the bank does not process payments [3].

To limit dependence on a single service provider, it may be advantageous to keep two master accounts at different banks. In addition, each currency should have its own master account (unless a hybrid cash pooling system is chosen).

\section{Zero balancing or target balancing}

It is now necessary to choose a suitable transaction model. With zero balancing, the associated accounts are set to zero at the affiliated companies on workdays or in some other regular manner and the balances are transferred to the master account. In contrast, target balancing only balances liquidity up to a previously agreed base amount.

\section{Conclusion}

Liquidity bundling offers obvious business advantages. All liquid capital is collected in one place, is centrally managed, and can be optimally distributed throughout the group so that it is less dependent on borrowed capital overall. However, you should always be aware of one thing when setting up this kind of system: Cash pooling is often a reason why the tax authorities may take a closer look. If you follow certain principles, however, you can minimize the risks and take advantage of the economic benefits of central liquidity management.

Nowadays, when the competition is very strong and the market situation is regularly subject to changes, it is necessary to find modern effective mechanisms for making a profit and increasing the economic growth of the enterprise. Any company must have the financial resources to be effectively used in business. An important tool for improving the distribution of enterprise funds is cash pooling. In the course of its activity, it is not easy for an enterprise to identify the optimal amount of money supply. Financial resources can be used ineffectively and not be profitable. If the enterprise does not invest in other forms of resources, then it will not be able to generate large income. Therefore, liquidity management, which is the pooling of 


\section{МЕЖДУНАРОДНЫЕ НАУЧНЫЕ ЧТЕНИЯ ИМЕНИ ЛАУРЕАТА НОБЕЛЕВСКОЙ ПРЕМИИ П.Л. КАПИЦЫ}

financial resources of a company, is an effective mechanism for optimizing the activities of an enterprise with a number of advantages [2].

\section{References}

1. Cash pooling // IONOS Startup guide. Grow Your Business. 2019. URL: https://www.ionos.com/startupguide/grow-your-business/cash-pooling/

2. Cash Pooling System // Cash Flow Analysis. 2019. URL: https://esrel2016.org/cash-pooling-effective-tool-for-optimization-and- managementof-internal-business-resources/

3. Taking control with cash pooling // IE Insights. 2019. URL: https://www.ie.edu/insights/articles/taking-control-with-cash-pooling/

4. Using cash pooling to optimize financial results // Illumeo. 2020. URL: https://www.illumeo.com/courses/cash-pooling

5. Roussel A. Cash Pooling - Definition // DataLog Finance. 2018. URL: https://www.datalog-finance.com/en/definition-cash-pooling-2/

6. 5 ways to optimize business cash flow // Quickbooks. 2018. 8. URL: https://www.tradegecko.com/blog/small-business-growth/5-ways-to-optimizebusiness-cash-flow

7. Cash pooling // ANZ. 2019. URL: https://www.anz.com/institutional/ solutions/payments-cash-management/cash-pooling/

8. Biehler A. Leveraging netting and cash pooling for an in-house bank // Coupa. 2019. URL: https://www.coupa.com/blog/treasury/leveraging-netting-andcash-pooling-for-house-bank

9. Kadlecová J. Cash Pooling and Its Accounting Treatment // Deloitte. 2018. URL: https://www.dreport.cz/en/blog/cash-pooling-and-its-accounting-treatment/

10. Cash Pooling: Optimise your company's treasury management // Santander. 2020. URL: https://www.bancosantander.es/en/empresas/cobros-pagos/cashmanagement/cash-pooling

11. Cash is king. Establishing effective cash concentration structures. 2017. URL: $\quad$ https://www.pwc.com.cy/en/publications/assets/cash-is-king-establishingeffective-cash-concentration-structures.pdf 